\title{
Physico-Chemical Analysis of Soil from some Farms of Digras Region of District Yavatmal in Maharashtra, India
}

\author{
R.R.Wankhade
}

Department of Chemistry, B.B.Arts, N.B.Commerce \& B.P.Science College, Digras, Maharashtra, India.

oScholedge International Journal of Multidisciplinary \& Allied Studies (ISSN 2394-336X), Vol.02, Issue 10 (2015) p1-4. Published by: Scholedge R\&D Center [www.theSCHOLEDGE.org] [Email: sijmas@scholedge.org]

\begin{abstract}
:
The yield of the crop is dependent of the type of the soil and proper cultivation. Hence it is necessary to study some parameters of the soil. So in the present study is undertaken to determine the physico-chemical characteristics of some samples of soil from some farms of nearby villages of Digras region, Dist. Yavatmal.The soil characterization was carried out with respect to particle size distribution, bulk density,maximum water holding capacity, available water capacity, hydraulic conductivity, soil $\mathrm{pH}$, electrical conductivity, cation exchange capacity, free calcium carbonate and organic carbon. The important observation during the study is that the parameters were fluctuating for farm to farm of nearby villages.
\end{abstract}

Key Words: Soil, Bulk Density, Electrical Conductivity, Organic Carbon, Available water capacity, Cation Exchange Capacity.

\section{Introduction}

The soil word is derived from Latin word, 'Solum' meaning the earthy material in which plant growth occurs. Soil is the natural material spread in different layers. It differs in physical, chemical and mineralogical characteristics. Soil is result of rocks due to environmental processes; weathering and erosion. Soil ius dynamic material of minerals, organic matter, water, air, bacteria etc. Soil quality varies due to farming, parent material and environmental changes.

Yavatmal district is the region of Western Vidarbha; the part of Maharashtra. In this district and hence in Digras region the main crops are cotton, soyabean, jawari, bajari, toor etc. Essential nutrients required for proper growth of plants is supplied by soil. Hence the yield and quality of crop depends on the quality of soil. Various nutrients are supplied to soil from fertilizers. Productivity of crop is increased by use of various chemical fertilizers on large scale, but it is decreasing the quality of soil. So it is essential to carry out the physicochemical analysis of soil. 


\section{Materials and methods}

Three farms of each village were selected for physico-chemical analysis of soil. Total seven villages situated nearby Digras were selected for study. Average value of parameter of three selected farms of a village was reported. Soil samples were collected in the depth of 5-20 cm from the surface of soil and were taken in polythene bags. The soil samples were collected in the month of February 2015 from different sampling stations. Sample stations used from 'Digras region' are given in following table-1 and named as $\mathrm{S}_{1}, \mathrm{~S}_{2}, \mathrm{~S}_{3}, \mathrm{~S}_{4}, \mathrm{~S}_{5}, \mathrm{~S}_{6}$ and $\mathrm{S}_{7}$.

Table-1

\begin{tabular}{|c|l|}
\hline Sample site & Name of Village \\
\hline$S_{1}$ & Kalasa \\
\hline$S_{2}$ & Rohana Devi \\
\hline$S_{3}$ & Bori \\
\hline$S_{4}$ & Isapur \\
\hline$S_{5}$ & Kathi \\
\hline$S_{6}$ & Nimbha \\
\hline$S_{7}$ & Vitholi \\
\hline
\end{tabular}

The soil samples were collected and brought to the laboratory for the study of physicochemical parameters. The standard methods of soil analysis Black (1965P) and Richard(1945) for particle size distribution, bulk density, maximum water holding capacity, available water capacity, hydraulic conductivity and Piper (1966) for soil pH, electrical conductivity, cation exchange capacity, free calcium carbonate and organic carbon were adopted.

\section{Result and discussion}

Particle Size Distribution (Soil Texture) : Out of three categories of particle size of soil; sand particles are largest, slits are intermediate and clay particles are very fine. On the basis of relative proportion of these particles, soil texture is determined. Particle size distribution is given in table-1. The range of sand content in soil under study was $15.2 \%$ to $42.3 \%$, slit content was in the range of $18.5 \%$ to $30.1 \%$ and clay content was from $29.5 \%$ to $66.8 \%$, Hence the soil texture varied from clay to clay loam with predominance of clay texture. The soil texture influence water availability. The sandy soil quickly be recharged with soil moisture but is unable to hold much water as like soil with heavier texture.

Bulk Density And Porosity: Bulk density of soil is the mass per unit volume. Thus it measures space occupied by solids pore space i.e. degree of compactness of soil. It decreases with increase in organic matter. In this study, Bulk Density varied from 1.12 to $1.23 \mathrm{mg} / \mathrm{m}^{3}$. Porosity of soil sample ranged from 52.7 to $57.4 \%$. 
Maximum Water Holding Capacity and available Water Capacity: Good water holding capacity indicates the good physical condition of soil. The maximum water holding capacity was observed from 55.6 to $71.3 \%$. The available water capacity of soil sample ranged from 11.9 to $17.2 \%$.

Hydraulic Conductivity: It depends upon clay content and pore size of soil. Hydraulic conductivity values for samples under study ranged from 0.21 to $0.96 \mathrm{cmhr}^{-1}$.

Table -2: Physico-chemical parameters of different soil samples

\begin{tabular}{|c|c|c|c|c|c|c|c|c|}
\hline S.No. & Parameter & $\mathrm{S}_{1}$ & $\mathrm{~S}_{2}$ & $\mathrm{~S}_{3}$ & $\mathrm{~S}_{4}$ & $\mathrm{~S}_{5}$ & $\mathrm{~S}_{6}$ & $\mathrm{~S}_{7}$ \\
\hline 01 & Sand (\%) & 15.4 & 15.2 & 28.9 & 37.6 & 42.3 & 39.2 & 38.7 \\
\hline 02 & Slit (\%) & 27.7 & 21.4 & 8.5 & 19.5 & 28.1 & 30.1 & 23.6 \\
\hline 03 & Clay (\%) & 66.8 & 62.4 & 62.4 & 42.7 & 29.5 & 30.7 & 37.5 \\
\hline 04 & Textural Class & $C$ & $\mathrm{C}$ & $\mathrm{C}$ & $C$ & $\mathrm{CL}$ & $\mathrm{CL}$ & $\mathrm{CL}$ \\
\hline 05 & Bulk density $\left(\mathrm{mgm}^{-3}\right)$ & 1.14 & 1.12 & 1.17 & 1.17 & 1.23 & 1.19 & 1.18 \\
\hline 06 & Porosity (\%) & 53.7 & 54.9 & 57.4 & 54.6 & 52.7 & 53.6 & 52.9 \\
\hline 07 & $\begin{array}{l}\text { Maximum Water Holding } \\
\text { Capacity (\%) }\end{array}$ & 71.3 & 65.8 & 67.3 & 55.6 & 58.2 & 60.5 & 69.6 \\
\hline 08 & $\begin{array}{l}\text { Available Water Capacity } \\
(\%)\end{array}$ & 14.6 & 17.2 & 16.7 & $15 \cdot 9$ & 11.9 & 13.4 & 12.4 \\
\hline 09 & $\begin{array}{l}\text { Hydraulic } \\
\left(\mathrm{cmhr}^{-1}\right)\end{array}$ & 0.41 & 0.36 & 0.68 & 0.73 & 0.96 & 0.82 & 0.71 \\
\hline 10 & $\mathrm{pH}$ & 7.35 & 6.85 & 7.41 & 7.28 & 7.41 & 8.04 & 7.63 \\
\hline 11 & $\begin{array}{l}\text { Electrical Conductivity } \\
\left(\mathrm{dSm}^{-1}\right)\end{array}$ & 0.23 & 0.26 & 0.18 & 0.24 & 0.35 & 0.35 & 0.35 \\
\hline 12 & Organic Carbon $\left(\mathrm{gKg}^{-1}\right)$ & 6.7 & 7.2 & 5.2 & 6.9 & 7.6 & 8.5 & 7.4 \\
\hline 13 & Calcium Carbonate (\%) & $15 \cdot 32$ & 10.4 & $15 \cdot 30$ & 9.7 & 5.14 & 5.16 & 11.2 \\
\hline 14 & $\begin{array}{l}\text { Cation Exchange } \\
\text { Capacity }(\mathrm{cmol}(\mathrm{p}+) \mathrm{Kg} \text { ha } \\
\left.{ }^{1}\right)\end{array}$ & 40.2 & 51.6 & 49.7 & $67 \cdot 3$ & 52.8 & 53.1 & 47.4 \\
\hline
\end{tabular}

pH and Electrical conductivity: $\mathrm{pH}$ is an important parameter as it measures availability of nutrients like $\mathrm{Fe}, \mathrm{Mn}, \mathrm{Zn}$ and $\mathrm{Cu}$ which are more available in acidic soil than alkaline soil. Soil with $\mathrm{pH} 6.85$ to 7.5 is considered to have most of the nutrients available for plants. The $\mathrm{pH}$ value of analysed soil samples ranged from 6.83 to 8.04 . Only sample $S_{2}$ is acidic.

The measurement of electrical conductivity (EC) is to determine amount of salts soluble in soil.EC values ranged from 0.18 to $0.35 \mathrm{dSm}^{-1}$. Higher $E C$ values were found for samples $S_{5}, S_{6}$, $\mathrm{S}_{7}$. 
Organic Carbon: In the soil crop residue, animal manure, cover crops, green manure, organic fertilizers etc. are main sources of organic carbon. In this sense it an index of nitrogen. Organic carbon in soil samples studied was found in the range of 5.2 to $8.5 \mathrm{gKg}^{-1}$. The lowest value was for $S_{3}$ and highest value was for $S_{6}$.

Calcium Carbonate and Cation Exchange Capacity: In the irrigation soils calcium carbonate occurs in natural state. Soil fertility is not uniformly affected by the presence of carbonates. Calcium carbonate values ranged from 5.14 to $15.32 \%$. Lower calcium carbonate value was recorded for $\mathrm{S}_{5} \& \mathrm{~S}_{6}$ and higher value was for $\mathrm{S}_{1} \& \mathrm{~S}_{3}$.

Cation exchange capacity (CEC) denotes the ability of soil to hold nutrient cations in readily available forms. It is the quantity of nutrient cations present in exchangeable form. CEC influence $\mathrm{pH}$ of soil and its salt composition. It is the direct source of mineral nutrients to plants. It affect the physical properties of soil. The CEC values were found between 40.2 to $67.3 \mathrm{cmol}(\mathrm{p}+) \mathrm{Kgha}^{-1}$. Lower $\mathrm{CEC}$ was observed for $\mathrm{S}_{1}$ and higher value was observed for $\mathrm{S}_{4}$.

\section{Conclusion}

Physico-chemical analysis of soil under study show different values for various sites. Most of the soil samples are alkaline in character. The texture of soil raged from clay to loam clay. Physico-chemical parameter values suggest no any pollution effect. The fertilizers used by farmers of this region use well combination of chemical and manure fertilizers.

\section{References}

1. P.P.Raut, P.D.Ekbote, Physico-chemical analysis of soil collected from Babhulgaon region, dist. Yavatmal (M.S.). International journal of basic and applied research,Oct. 2012,page112-116..

2. A.N.kulkarni, J.B.Balkhande, B.D.Waghamare, P.U.Ratnakar and V.S.Kanwate, Studies of some physico-chemical factors of teak forest from Kinwat area, Nanded (Maharashtra). International journal of life science(2011) page437-438.

3. Jagdish Prasad, Nagraju,Raveev Shrivastava, S.K.Ray and P.Chandran, Characteristic and classification of some soil in Nagpur district. I.India Soc. Soil sci. 49(4), 2001,page 735-739.

4. C.A.Black, Method of Soil analysis, part-l, Amar Soc.Agron. Inc. Argon No.9; Madison, USA, 1965. 